\title{
COMPARISON OF VEHICLE PERFORMANCE USING FOSSIL DIESEL FUEL BLENDS WITH BIODIESEL AND HVO FUEL
}

Kristaps Sondors, Aivars Birkavs, Vilnis Pirs, Gints Birzietis, Ilmars Dukulis

Latvia University of Life Sciences and Technologies, Latvia

kristaps.sondors@gmail.com, aivars.birkavs@1lu.lv, vilnis.pirs@1lu.lv, gints.birzietis@1lu.lv, ilmars.dukulis@1lu.lv

\begin{abstract}
Biodiesel is increasingly used as an additive to fossil diesel fuel. For summer periods it is compulsorily in Latvia to use diesel fuel with $4.5-7 \%$ biodiesel fuel mix. Some technical disadvantages of biodiesel/fossil diesel blends are mentioned by many researchers, for example, reduced energy density, and degradation of fuel under storage for prolonged periods. Therefore, one of the solutions might be blending of different biofuels instead of biodiesel. Hydrotreated vegetable oil (HVO) is one of the most promising next generation biofuels in the near future. An unmodified passenger car Opel Insignia 2.0 CDTi (manufactured in 2011) with a four-cylinder diesel engine (power $96 \mathrm{~kW}$ ) has been investigated. Chassis dynamometer Mustang MD-1750, AVL KMA MOBILE fuel consumption meter, and AVL SESAM FTIR multi-component exhaust gas measurement system were used during the experiments. Running the car with diesel fuel mixed with $7 \%$ of biodiesel, it developed $2.1 \%$ less maximum power and $1.3 \%$ less maximum torque compared with fossil diesel, and about $2.3 \%$ less power and $1.5 \%$ less torque compared to diesel fuel blended with $7 \%$ HVO fuel. Diesel fuel $1 / 7 \%$ biodiesel blend fuel consumption is in average $3.1 \%$ higher compared to pure fossil diesel, and in average $3.0 \%$ higher in comparison with diesel fuel mixed with $7 \% \mathrm{HVO}$ fuel. Blend of $7 \% \mathrm{HVO}$ with fossil diesel fuel compared to diesel fuel mix with $7 \%$ of biodiesel approximately by $4 \%$ decreases the amount of $\mathrm{NO}_{\mathrm{x}}$, by $3 \% \mathrm{CO}_{2}$, and about 3.5 times unburnt hydrocarbon content in exhaust gases, but $\mathrm{CO}$ increases by approximately $90 \%$.
\end{abstract}

Key words: diesel fuel, biodiesel, hydrotreated vegetable oil.

\section{Introduction}

The European Commission has proposed to limit the amount of first-generation biofuels up to $5 \%$ and to increase incentives for modern biofuels, for example, for those produced from waste and other non-food biomass, including algae and microorganisms. After 2020 the state aid should be available only for the next generation, i.e. second, third and even fourth generation biofuels. The European Commission Communication "Clean Power for Transport: A European alternative fuels strategy" states that the future of mobility does not have a single fuel solution and that all major alternative fuels must be found, focusing on the needs of each mode of transport. A strategic approach for the EU should therefore be based on a combination of alternative fuels without favouring a specific fuel [1].

Hydrotreated vegetable oil (HVO) is one of the most promising next generation biofuels in the near future. Catalytic hydroprocessing technology can convert raw vegetable oils, waste cooking oils, animal fats and algae oils into biofuel with high calorific value, high cetane number, increased saturation level and oxidation stability [2].

HVO biofuels have been tested in several countries. For example, in South Korea a 1.5-liter DOHC diesel engine was used to measure power differences using blends of biodiesel and HVO with fossil diesel. The results of the study showed the reduction of power using fuel blends. For example, adding $2 \%$ biodiesel to fossil diesel resulted in decrease of power for about $1.4 \%$, but $10 \%$ blend showed decrease of power for about $2.0 \%$. Blending the same amount of HVO with fossil diesel, the power decrease was $0.7 \%$ and $1.2 \%$ accordingly. The fuel consumption of biodiesel blend with diesel fuel increases as the mixing factor increases (from about $0.5 \%$ to $2 \%$ ), but $\mathrm{HVO}$ blends showed a slight increase in fuel consumption (from about $0.1 \%$ to $0.3 \%$ ). Blending $10 \%$ biodiesel to fossil diesel decreases unburned hydrocarbon (HC) content comparing with fossil diesel, while the content of $\mathrm{CO}, \mathrm{NO}_{\mathrm{x}}$ and $\mathrm{CO}_{2}$ stays the same. $10 \% \mathrm{HVO}$ blend decreases $\mathrm{CO}, \mathrm{HC}$ and $\mathrm{CO}_{2}$ content comparing with both pure fossil diesel and biodiesel/diesel blend [3].

Emissions from two Euro $6 \mathrm{~b}$ diesel passenger cars using different blends of $\mathrm{HVO}$, fossil diesel and commercial diesel (Bio7) were investigated at $23{ }^{\circ} \mathrm{C}$ and $-7{ }^{\circ} \mathrm{C}$ in Italy [4]. Overall, the use of different HVO blends did not lead to fuel related trends on the emissions of the tested vehicles in the laboratory nor on-road. 
Another experimental result [5] proved that $\mathrm{HVO}$ blends give a benefit on both fuel consumption and $\mathrm{CO}_{2}$ saving.

All these results, as well as HVO reviews [2; 6; 7], allow to conclude that the trends in power, fuel consumption and emissions are very different, depending on the type of the engine used, test conditions, and so on. Moreover, most of the experiments are carried out using engine test beds, but not by testing vehicles in general.

That is why in this experiment as a test car Opel Insignia 2.0 CDTi was used - a car is popular in Europe, and is produced at the time (2011) that roughly corresponds to the average age of passenger cars in European countries.

\section{Materials and methods}

Research has been carried out at the Alternative Fuel Research Laboratory of the Latvia University of Life Sciences and Technologies. The power, torque, fuel consumption and exhaust gas content of the car were measured using three different fuel samples:

- standard fossil diesel fuel (DF);

- fossil diesel fuel with $7 \%$ (by volume) blend of biodiesel (Bio7);

- fossil diesel fuel with $7 \%$ (by volume) blend of HVO (HVO7).

The main fuel parameters were determined at an independent certified laboratory (See Table 1).

Main parameters of tested fuels

Table 1

\begin{tabular}{|l|c|c|c|}
\hline \multicolumn{1}{|c|}{ Parameter } & DF & Bio7 & HVO7 \\
\hline Density at $15^{\circ} \mathrm{C}, \mathrm{kg} \cdot \mathrm{m}^{-3}$ & 833.9 & 837.2 & 830.0 \\
\hline Viscosity at $40^{\circ} \mathrm{C}, \mathrm{mm}^{2} \cdot \mathrm{s}^{-1}$ & 2.834 & 2.917 & 2.814 \\
\hline Lowest heating value $\left(\mathrm{LHV}_{\text {mass }}\right), \mathrm{MJ} \cdot \mathrm{kg}^{-1}$ & 43.52 & 43.02 & 43.62 \\
\hline Lowest heating value $\left(\mathrm{LHV}_{\text {volume }}\right),{\mathrm{MJ} \cdot \mathrm{l}^{-1}}^{\text {Cetane number }}$ & $36.29^{*}$ & $36.02^{*}$ & $36.21^{*}$ \\
\hline Water content, $\mathrm{mg} \cdot \mathrm{kg}^{-1}$ & 52.5 & 52.8 & 52.6 \\
\hline
\end{tabular}

$-\mathrm{LHV}_{\text {volume }}$ in $\mathrm{MJ} \mathrm{I}^{-1}$ is calculated form measured $\mathrm{LHV}_{\text {mass }}$ in $\mathrm{MJ} \mathrm{kg}^{-1}$ and density

The car Opel Insignia 2.0 CDTi (year of production - 2011, mileage - $56580 \mathrm{~km}$ ) with a fourcylinder diesel engine (engine displacement $1956 \mathrm{~cm}^{3}$, maximum power of $96 \mathrm{~kW}$ at $4000 \mathrm{~min}^{-1}$, and maximum torque $300 \mathrm{~N} \cdot \mathrm{m}$ at $1750 \mathrm{~min}^{-1}$ ) was used as the test vehicle.

The chassis dynamometer Mustang MD-1750 was used for the power and torque measurement on the vehicle wheels. The main characteristic of the chassis dynamometer used in the test:

- maximum measuring capacity - $1750 \mathrm{hp}$;

- maximum absorption capacity - $400 \mathrm{hp}$;

- maximum measuring speed $-360 \mathrm{~km} \cdot \mathrm{h}^{-1}$;

- maximum axle load on rollers $-4500 \mathrm{~kg}$.

Fuel consumption was measured by the AVL KMA Mobile measuring device, which is designed to measure fuel consumption in both laboratory and road conditions. The device is equipped with all the necessary components to measure the fuel consumption of diesel and gasoline engines. The $A V L K M A$ Mobile measurement module is based on the high-precision flow meter PLU-121, using the worldwide proved PLU measurement principle.

The exhaust components of the vehicle were measured by the emission measurement system $A V L$ SESAM FTIR (System for Emission Sampling and Measurement, FTIR - Fourier Transform Infra Red), which is designed for measurement of exhaust components for gasoline and diesel engines in different operating modes. With this system it is possible to measure up to 25 different exhaust components simultaneously, of which the main ones are: $\mathrm{C}_{2} \mathrm{H}_{2} ; \mathrm{C}_{2} \mathrm{H}_{4} ; \mathrm{C}_{2} \mathrm{H}_{6} ; \mathrm{C}_{3} \mathrm{H}_{8} ; \mathrm{C}_{4} \mathrm{H}_{6} ; \mathrm{C}_{4} \mathrm{H}_{8} ; \mathrm{CH}_{4}$; $\mathrm{CO}_{2} ; \mathrm{CO} ; \mathrm{H}_{2} \mathrm{O} ; \mathrm{HCHO} ; \mathrm{HCN} ; \mathrm{HCOOH} ; \mathrm{HNCO} ; \mathrm{N}_{2} \mathrm{O} ; \mathrm{NC}_{10} ; \mathrm{NC}_{8} ; \mathrm{NH}_{3} ; \mathrm{NO}_{2} ; \mathrm{NO} ; \mathrm{SO}_{2}$.

Schematic view of the experimental setup is shown in Figure 1. 


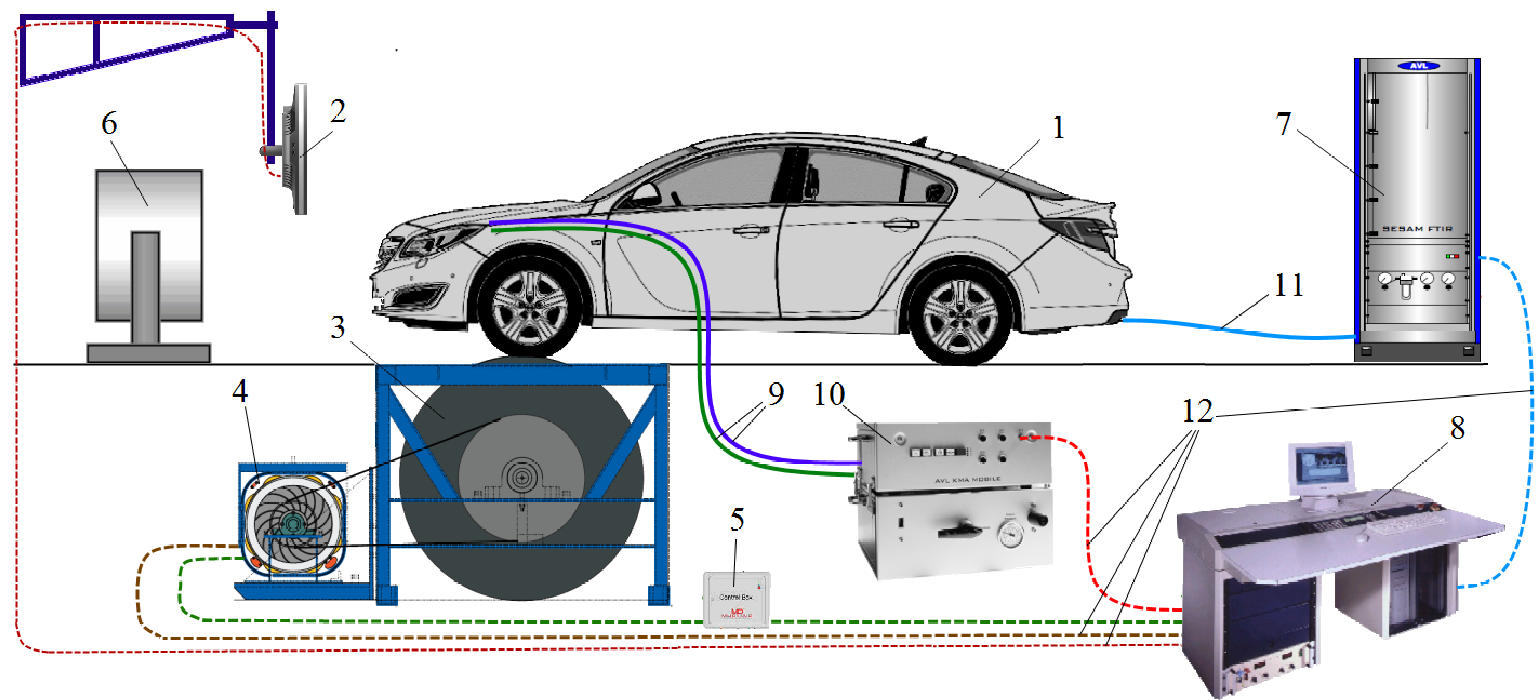

Fig. 1. Schematic view of experimental setup: 1 - experimental car; 2 - test cycle simulation screen; 3 - chassis dynamometer Mustang MD-1750; 4 - power absorber unit (PAU); 5 - dynamometer control box; 6 - air blower; 7 - multicomponent exhaust gas measurement system AVL SESAM FTIR; 8 - Mustang chassis dyno control module \& PC with special software AVL \& data recording; 9 - fuel lines; 10 - fuel measuring device AVL KMA Mobile; 11 - heated gas line for exhaust gas measurement from the exhaust tailpipe; 12 - AVL date communication cable \& Mustang dyno date communication cable \& dyno control circuit \& screen communication cable

The experimental methodology included a series of tests with each of the fuel samples (primarily diesel fuel with a $7 \%$ biodiesel blend, fossil diesel and, finally, diesel fuel with $7 \%$ HVO fuel mix): power tests, idle tests, constant speed tests and driving cycle tests. The scheme of the experimental methodology and the logical sequence of tests are given in Figure 2. Each series of tests were performed with at least 3 repetitions. Each subsequent repetition was made when all the tests in the previous series were completed. The air temperature in the test room was maintained between $+18{ }^{\circ} \mathrm{C}$ and $+21{ }^{\circ} \mathrm{C}$.

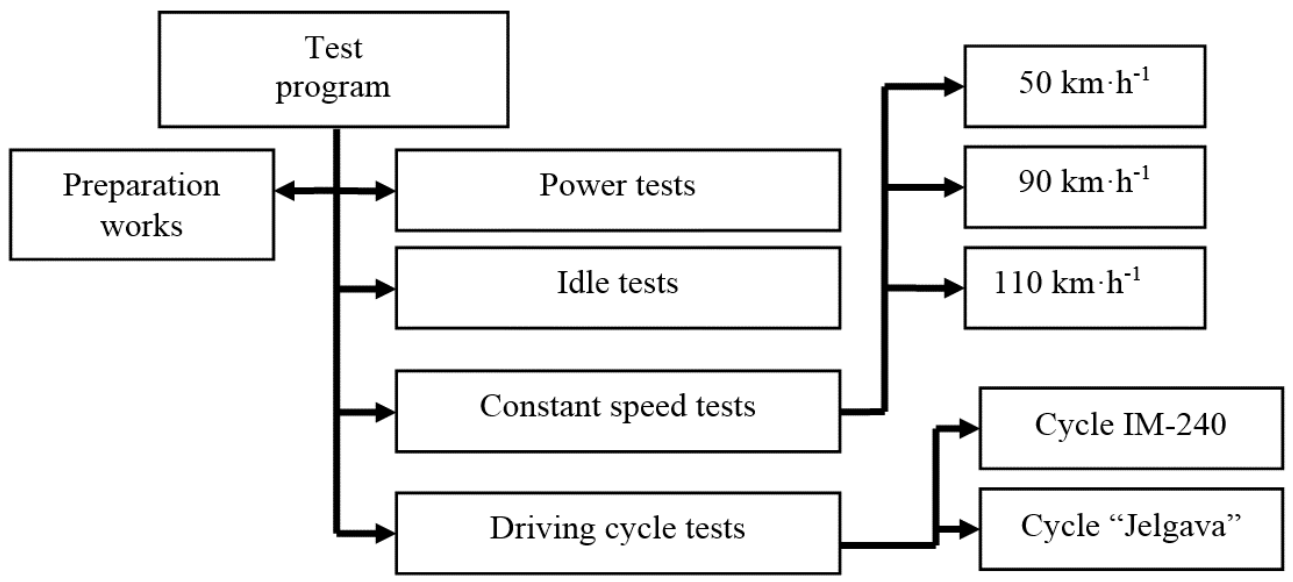

Fig. 2. Scheme of experimental methodology and logical sequence of tests

For determination the maximum power value, foremost the maximum power values were determined for each measurement repetition at the respective engine crankshaft rotation frequency. The final value was calculated as the average value from the repetitions of the particular measurements. The average fuel consumption (litres per $100 \mathrm{~km}$ ) in constant speed mode was calculated from the instant fuel consumption $\left(1 \cdot \mathrm{h}^{-1}\right)$, test time $(\mathrm{s})$ and the speed $\left(\mathrm{km} \cdot \mathrm{h}^{-1}\right)$ by the following relationship:

$$
Q_{100}=\frac{1}{n} \cdot \sum_{i=1}^{n}\left(\frac{100}{v \cdot t} \cdot \sum_{i=1}^{k} Q_{i n s t}\right),
$$


where $Q_{100}$ - average fuel consumption, 1 per $100 \mathrm{~km}$;

$n$ - number of repetitions;

$v$ - vehicle speed, $\mathrm{km} \cdot \mathrm{h}^{-1}$;

$t$ - duration of one test repetition, $\mathrm{s}$;

$k$ - number of instant measurements;

$Q_{\text {inst }}-$ instant fuel consumption, $1 \cdot \mathrm{h}^{-1}$.

The average fuel consumption during the driving cycle (litres per $100 \mathrm{~km}$ ) was determined by relationship:

$$
Q_{100}=\frac{1}{n} \cdot \sum_{i=1}^{n}\left(\frac{100 \cdot t}{3600 \cdot s} \cdot \sum_{i=1}^{k} Q_{i n s t}\right),
$$

where $s$-distance travelled during the repetition, $\mathrm{km}$.

The relative quantity of each exhaust gas component in all test modes was determined by the relationship:

$$
E G C=\frac{1}{n} \cdot \sum_{i=1}^{n}\left(\frac{1}{t} \cdot \sum_{i=1}^{k} E G C_{i n s t}\right),
$$

where $E G C$ - average relative quantity of the exhaust gas component, ppm or \%; $E G C_{\text {inst }}$ - instant relative amount of the exhaust gas component, ppm or $\%$.

The results of the tests are shown in Figures 3, 4 and 5.

\section{Results and discussion}

Comparing the average values of power and torque with the values of each individual repetition, the correlation for the torque data points exceeded $99.8 \%$, and for the power $-99.9 \%$. The power and torque curves were designed using the power and torque average values at specific speeds and operating the Opel Insignia with three different fuels (DF, Bio7 and HVO7) (see Fig. 3).
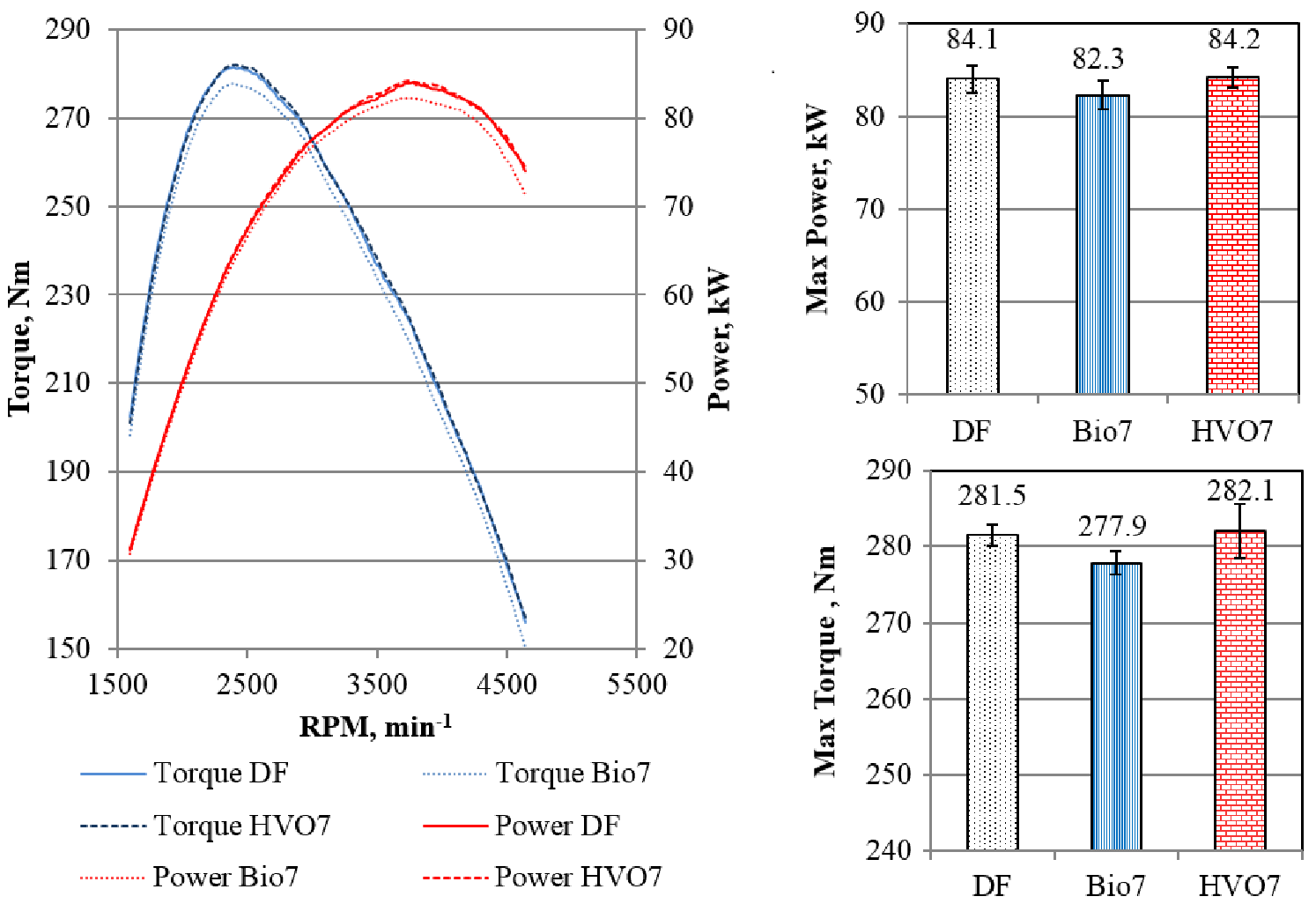

Fig. 3. Power and torque measurement results for Opel Insignia car using three different fuels 
The experimental results showed that with fossil diesel and diesel fuel blended with $7 \%$ of HVO fuel the car's power and torque curves in all range of the engine crankshaft rotation frequency were similar - the variation in power and torque values in all measured data points did not exceed $0.8 \%$.

The maximum car power with fossil diesel $84.1 \mathrm{~kW}$ was reached at $3780 \mathrm{~min}^{-1}$, with diesel fuel blended with $7 \%$ biodiesel $-82.3 \mathrm{~kW}$ at $3760 \mathrm{~min}^{-1}$, but with diesel fuel blended with $7 \% \mathrm{HVO}$ fuel $-84.2 \mathrm{~kW}$ at $3740 \mathrm{~min}^{-1}$.

The maximum power difference for fossil diesel and diesel fuel blended with $7 \% \mathrm{HVO}$ fuel was $0.16 \%$, which was considered as insignificant. Using $7 \%$ biodiesel blend, the developed power was $2.12 \%$ lower comparing with fossil diesel and $2.28 \%$ lower than for diesel fuel blended with $7 \%$ HVO fuel.

The maximum torque using fossil diesel $281.5 \mathrm{~N} \mathrm{~m}$ was reached at $2400 \mathrm{~min}^{-1}$, with diesel fuel mixed with $7 \%$ biodiesel $-277.9 \mathrm{~N} \mathrm{~m}$ at $2380 \mathrm{~min}^{-1}$, but with diesel fuel blended with $7 \% \mathrm{HVO}$ fuel $-282.1 \mathrm{~N}$ m at $2380 \mathrm{~min}^{-1}$ (see Fig. 3).

The maximum torque difference for fossil diesel and diesel fuel blended with $7 \%$ HVO fuel was $0.20 \%$, which was considered as insignificant. Using $7 \%$ biodiesel blend the torque was $1.3 \%$ less comparing with fossil diesel and $1.5 \%$ less than for diesel fuel blended with $7 \%$ HVO fuel.

The fuel consumption measurement errors were calculated at $95 \%$ confidence level. The fuel consumption results are shown in Fig. 4.

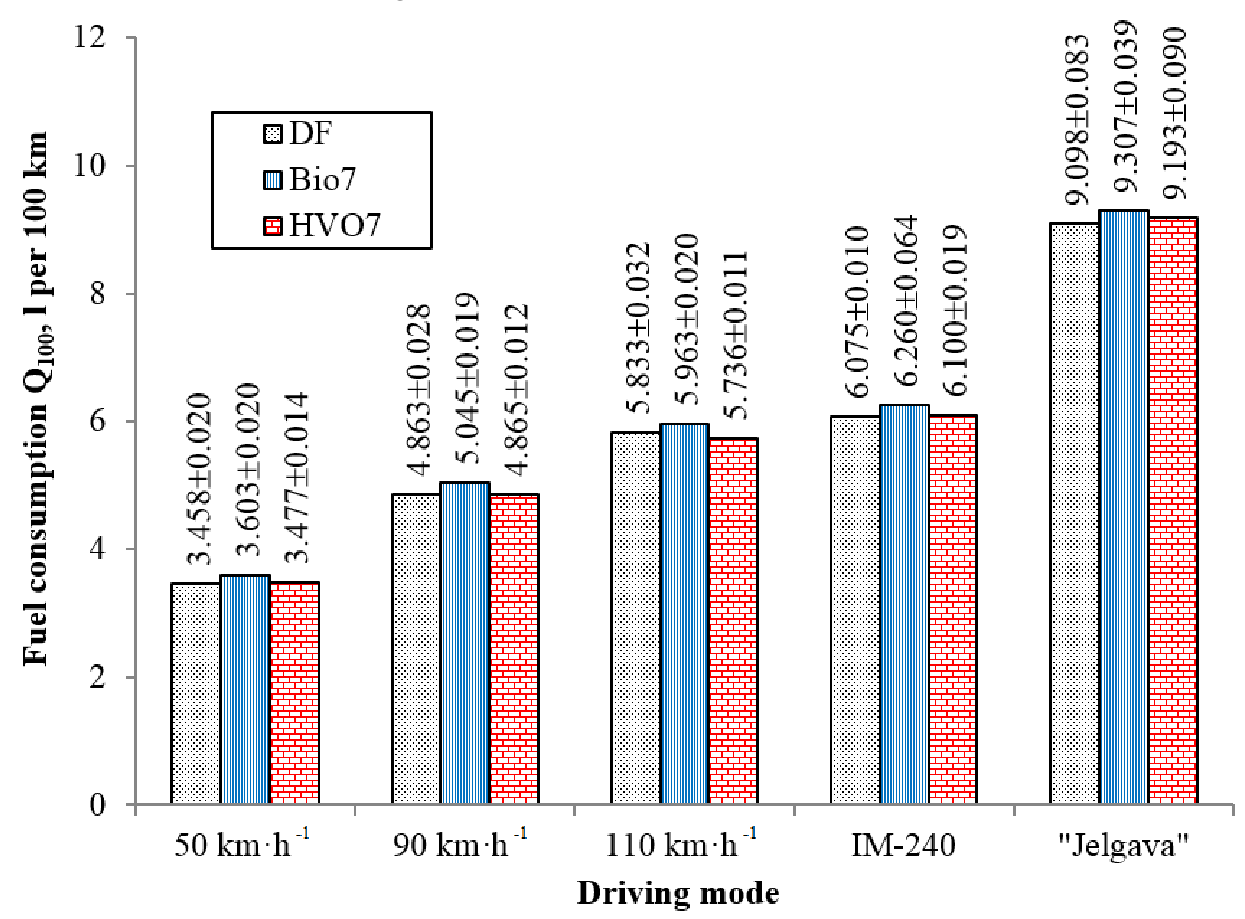

Fig. 4. Fuel consumption in different driving modes operating Opel Insignia car on three different fuels

The average idle fuel consumption for diesel fuel was $0.536 \pm 0.003 \mathrm{l} \cdot \mathrm{h}^{-1}$, for diesel fuel blend with $7 \% \mathrm{HVO}-0.531 \pm 0.0031 \cdot \mathrm{h}^{-1}$, and diesel fuel blend with $7 \%$ biodiesel $-0.538 \pm 0.003 \mathrm{l} \cdot \mathrm{h}^{-1}$. Considering that idle fuel consumption is most affected by various test conditions (e.g. engine temperature), these differences (within $1 \%$ range) cannot be considered as significant. Therefore, exactly the different driving modes more objectively characterize the changes in fuel consumption.

The calculated mean values in three constant speed tests $-50,90$ and $110 \mathrm{~km} \cdot \mathrm{h}^{-1}$, as well as in two types of cycles - standardised IM-240 and self-designed cycle "Jelgava" [8] allowed to observe that the average fuel consumption for fossil diesel fuel and diesel fuel blend with $7 \%$ HVO differs only by $0.07 \%$, which is considered to be an insignificant difference. Operating the car with the diesel fuel blend with $7 \%$ biodiesel, the fuel consumption was in average $3.11 \%$ higher than for fossil diesel fuel and in average $3.03 \%$ higher than for diesel fuel blend with $7 \% \mathrm{HVO}$ fuel. 
The changes of $\mathrm{NO}_{\mathrm{x}}$, unburned hydrocarbons $(\mathrm{HC}), \mathrm{CO}_{2}$ and $\mathrm{CO}$ content in exhaust gases operating the car on all three fuels are shown in Fig. 5. The content of all exhaust gases is given in ppm (parts per million). The same methodology as for fuel consumption was used for error calculation, only the exhaust gas component errors are not displayed as numerical values, but error bars at $95 \%$ confidence level.
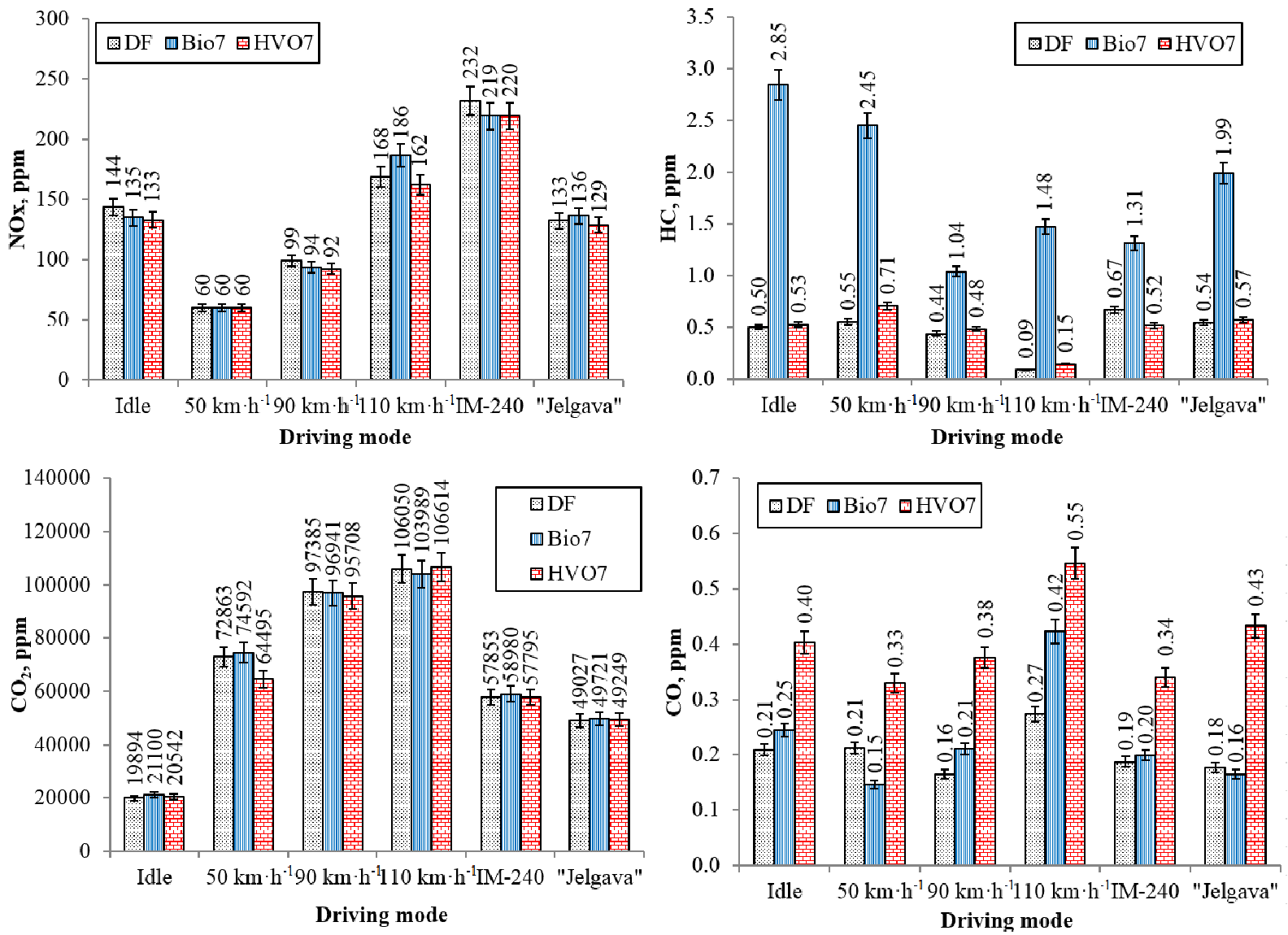

Fig. 5. Changes in NOx, $\mathrm{HC} \mathrm{CO}_{2}$ and $\mathrm{CO}$ content in exhaust gases running Opel Insignia car on three different fuels

The following evaluation of the results is based on the average value of measurements obtained by compiling all test modes used in this study.

The use of diesel fuel blended with $7 \%$ biodiesel in comparison to fossil diesel fuel practically does not change the $\mathrm{NO}_{x}$ content in exhaust gases, but the $\mathrm{CO}_{2}$ content rises insignificantly $(\sim 1.6 \%)$. The CO content increases by about $9 \%$ and the content of unburnt hydrocarbons increases by about 5 times.

Diesel fuel blended with $7 \% \mathrm{HVO}$ in comparison to fossil diesel practically does not change the $\mathrm{CO}_{2}$ content in exhaust gases, and the $\mathrm{NO}_{\mathrm{x}}$ content reduces by about $4.5 \%$. The unburnt hydrocarbon content increases by about $15 \%$, and $\mathrm{CO}$ - about 2 times.

The use of diesel fuel blended with $7 \% \mathrm{HVO}$ fuel in comparison to diesel fuel blended with $7 \%$ biodiesel reduces $\mathrm{NO}_{\mathrm{x}}$ by about $4 \%, \mathrm{CO}_{2}$ by $3 \%$, and the $\mathrm{HC}$ content about 3.5 times, while $\mathrm{CO}$ increases by about $90 \%$.

Comparing these results with the results of other studies confirms mentioned in the introduction, i.e., the trends in changes of power, fuel consumption and emissions in different investigations are very various. For example, comparing with the results obtained in South Korea [3], there are similar trends in power reduction using biodiesel/diesel blends. But the reduction of power with HVO blends is not confirmed. Similar trends are in the changes of fuel consumption, $\mathrm{HC}$ and $\mathrm{CO}_{2}$ content, but the trends in $\mathrm{CO}$ change are sharply different. 


\section{Conclusions}

1. The study revealed that operating the Opel Insignia 2.0 CDTi car with fossil diesel fuel and diesel fuel blend with $7 \% \mathrm{HVO}$ fuel the power and torque curves in all engine crankshaft rotation frequency ranges were similar - the change of the power and torque values in all measured data points did not exceed $0.8 \%$.

2. The maximum power difference for fossil diesel fuel and diesel fuel blend with $7 \%$ HVO was $0.16 \%$. Diesel fuel blend with $7 \%$ biodiesel produced $2.12 \%$ lower maximum power compared to fossil diesel fuel and $2.28 \%$ less power than diesel fuel blend with $7 \% \mathrm{HVO}$.

3. The maximum torque difference for fossil diesel fuel and diesel fuel blend with $7 \%$ HVO was $0.20 \%$. Diesel fuel blend with $7 \%$ biodiesel generated $1.3 \%$ reduction in the maximum torque compared to fossil diesel fuel and $1.5 \%$ lower torque compared to diesel fuel blend with $7 \%$ HVO.

4. The difference in average fuel consumption for fossil diesel and diesel fuel blend with $7 \% \mathrm{HVO}$ was only $0.07 \%$. The diesel fuel blend with $7 \%$ biodiesel consumed on average $3.11 \%$ more than fossil diesel fuel and on average $3.03 \%$ more than diesel fuel blend with $7 \%$ HVO.

5. Running the car with the diesel fuel blend with $7 \%$ biodiesel $\mathrm{CO}$ emissions increased by about $9 \%$ and unburned hydrocarbons approximately 5 times compared to pure fossil diesel.

6. Using diesel fuel blend with $7 \% \mathrm{HVO}$ fuel, the $\mathrm{NO}_{\mathrm{x}}$ content was reduced by $4.5 \%$ compared to pure fossil diesel, the content of unburned hydrocarbons increased by about $15 \%$ and $\mathrm{CO}-2$ times.

7. Using diesel fuel blend with $7 \% \mathrm{HVO}$ in comparison to diesel fuel blend with $7 \%$ biodiesel, the $\mathrm{NO}_{\mathrm{x}}$ emission was lower by $4 \%, \mathrm{CO}_{2}$ and unburnt hydrocarbon emissions by $3 \%$, while $\mathrm{CO}$ was higher by $90 \%$.

8. The study showed that blending of $7 \%$ HVO to fossil diesel was more effective from all evaluated aspects than admixing $7 \%$ biodiesel fuel.

\section{References}

[1] Clean Power for Transport: A European alternative fuels strategy. Communication from the Commission to the European Parliament, the Council, the European Economic and Social Committee and the Committee of the Regions. European Commission, Brussels, 24.01.2013, $\operatorname{COM}(2013) 17$ final, $11 \mathrm{p}$.

[2] Sonthalia A., Kumar N. Hydroprocessed vegetable oil as a fuel for transportation sector: A review. Journal of the Energy Institute, No. 92, 2019, pp. 1-17. DOI: 10.1016/j.joei.2017.10.008

[3] Kim D., Kim S., Oh S., No S.-Y. Engine performance and emission characteristics of hydrotreated vegetable oil in light duty diesel engines. Fuel, No. 125, 2014, pp. 36-43. DOI: 10.1016/j.fuel.2014.01.089

[4] Suarez-Bertoa R., Kousoulidou M., Clairotte M., Giechaskiel B., Nuottimäki J., Sarjovaara T., Lonza L. Impact of HVO blends on modern diesel passenger cars emissions during real world operation. Fuel, No. 235, 2019, pp. 1427-1435. DOI: 10.1016/j.fuel.2018.08.031

[5] Napolitano P., Guido C., Beatrice C., Pellegrini L. Impact of hydrocracked diesel fuel and Hydrotreated Vegetable Oil blends on the fuel consumption of automotive diesel engines. Fuel, No. 222, 2018, pp. 718-732. DOI: 10.1016/j.fuel.2018.02.097

[6] No S.-Y. Application of hydrotreated vegetable oil from triglyceride based biomass to CI engines - A review. Fuel, No. 115, 2014, pp. 88-96. DOI: 10.1016/j.fuel.2013.07.001

[7] Sunde K., Brekke A., Solberg B. Environmental Impacts and Costs of Hydrotreated Vegetable Oils, Transesterified Lipids and Woody BTL - A Review. Energies, No. 4, 2011, pp. 845-877. DOI: $10.3390 /$ en 4060845

[8] Dukulis I., Pirs V. Development of Driving Cycles for Dynamometer Control Software Corresponding to Peculiarities of Latvia. Proceedings of the 15th International Scientific Conference "Research for Rural Development", May 20-22, 2009, Jelgava, Latvia, pp. 95-102. 